\title{
Marital Forgiveness: An Explanation Based on Human Values
}

\author{
Patricia Nunes da Fonsêca \\ Center for Education, Department of Psychopedagogy, Federal University of Paraiba, \\ João Pessoa, PB, Brazil \\ Bruna de Jesus Lopes ${ }^{1}$ \\ Center for the Humanities, Arts and Languages, Federal University of Paraiba, \\ João Pessoa, PB, Brazil \\ Estefânea Élida da Silva Gusmão \\ Center for Psychological Evaluation in Health, Department of Psychology, \\ Federal University of Ceará, Fortaleza, CE, Brazil \\ Viviany Silva Araújo Pessoa \\ Center for Education, Department of Psychopedagogy, Federal University of Paraiba, \\ João Pessoa, PB, Brazil \\ Ricardo Neves Couto \\ Center for the Humanities, Arts and Languages, Federal University of Paraiba, \\ João Pessoa, PB, Brazil \\ Maria Izabel Fernandes da Silva \\ Center for Education, Department of Psychopedagogy, Federal University of Paraíba, \\ João Pessoa, PB, Brazil
}

\begin{abstract}
This study aimed to understand the relationship between marital forgiveness and human values and to discover the latter's power to predict whether a marriage will recover. The study included 313 participants who were married or in a long-term relationship, 70\% from the state of Paraíba and 30\% from the state of Piauí. The participants' ages ranged from 18 to 70 years $(M=35.0 ; S D=11.41)$, the majority being female (67.7\%). The participants answered three questionnaires: the Marital OffenceSpecific Forgiveness Scale, the Basic Values Questionnaire, and a sociodemographic questionnaire. Two stepwise multiple linear regression analyses were conducted. The first, which took the value subfunctions as the predictive variables, found that the interactive subfunction explains marital forgiveness, directly contributing to the explanation of whether forgiveness is granted between couples. The second analysis took the type of orientation as explanatory variables. It found that social values directly contribute to explaining whether the marriage recovers. In light of these results, one may conclude that individuals who prioritize social values are more disposed to grant forgiveness within a marriage.
\end{abstract}

Keywords: Forgiveness, human values, marital relationship.

1 Mailing address: Federal University of Paraíba, Normative Bases of Social Behavior, Center for the Humanities, Arts and Languages, João Pessoa, PB, Brazil 58059-900. Phone: (+55) (83) 3216-7444. E-mail: pnfonseca.ufpb@gmail.com, bruna_lopespsi@hotmail.com, estefanea@gmail.com, viviany.pessoa@gmail.com, r.nevescouto@gmail.com and isabelfernandes_silva@hotmail.com 


\section{Perdão Conjugal: Uma Explicação a partir dos Valores Humanos}

\section{Resumo}

Teve-se como objetivo conhecer a relação entre o perdão conjugal e os valores humanos, bem como verificar o poder deste último em predizer a remissão marital. Para isso, contou-se com 313 pessoas, casadas ou em união estável, do estado da Paraíba (70\%) e do Piaú (30\%). As idades variaram de 18 a 70 anos $(M=35,00 ; D P=11,41)$, sendo a maioria do sexo feminino $(67,7 \%)$. Estes responderam os instrumentos: Escala de Perdão Conjugal, Questionário de Valores Básicos e um Questionário Sociodemográfico. Foram executadas duas Análises de Regressão Linear Múltipla (método Stepwise). Na primeira, tendo como variáveis previsoras as subfunções valorativas, constatou-se que a subfunção interativa explica o perdão conjugal. Contribuindo de forma direta na explicação da concessão do perdão entre casais. Na segunda, fixaram-se como variáveis explicativas os tipos de orientação. Esta revelou que os valores sociais explicam a remissão matrimonial, contribuindo de forma direta. Diante destes resultados, conclui-se que os indivíduos que priorizam valores sociais encontram-se mais predispostos a conceder o perdão dentro do casamento.

Palavras-chave: Perdão, valores humanos, conjugalidade.

\section{Perdón Civil: Una Explicación a partir de los Valores Humanos}

\section{Resumen}

Se objetivó conocer la relación entre perdón conyugal y valores humanos, y se buscó verificar el poder de este último para predecir la remisión marital. Se contó con 313 personas, casadas o en unión estable, del estado de Paraíba (70\%) y Piauí (30\%). Las edades oscilaron entre 18 y 70 años $(M=35,00 ; D E=$ 11,41), la mayoría mujeres (67,7\%). Ellos respondieron: Escala de Perdón Conyugal, Cuestionario sobre los Valores Básicos y el Cuestionario sociodemografico. Se realizaron dos Análisis de Regresión Lineal Múltiple (método Stepwise). En el primero, se considero como las variables predictoras las subfunciones valorativas, se encontró que la subfunción interactiva explica el perdón conyugal. Contribuyendo directamente en la explicación de la concesión del perdón entre las parejas. En el segundo, se fijaron como variables explicativas los tipos de orientación. Esto reveló que los valores sociales son responsables por explicar la remisión marital, lo que contribuye directamente. Teniendo en cuenta estos resultados, se concluye que las personas que dan prioridad a los valores sociales son más propensos a conceder el perdón en el matrimonio.

Palabras clave: Perdón, valores humanos, conyugalidad.

According to Bueno, Souza, Monteiro, and Teixeira (2013), marriage can be understood as the emergence of a new generation and the beginning of a new household. Day- to-day problems cannot entirely be avoided, but the manner in which a couple addresses adversity may contribute to instability or harmony within the relationship (Wagner \& Mosmann, 2012).

Fincham, Hall, and Beach (2006) indicate that forgiveness is an excellent strategy for maintaining a marital relationship because it helps reduce the impact of negative perceptions of the other and enhances conflict resolution and the stability of the marriage. However, although forgiveness has long been recognized as very important for the conservation of relationships, only in recent years has it caught the attention of researchers (Lin et al., 2014; Peets, Hodges, \& Salmivalli, 2013; Strelan, McKee, Claic, Cook, \& Shaw, 2013) as a result of the benefits 
that derive from the act of forgiveness, such as well-being (Allemand, Steiner, \& Hill, 2013), mental and physical health (Calo-Blanco, 2014), emotional stability (Lander, 2012), and marital satisfaction (Witvliet, 2001).

A growing body of research on this topic has led to the development of studies that seek to understand how it relates to other variables such as moral thought (Abreu, 2013), satisfaction with general health (Sales, 2014), and human values (Barbosa, 2015). Currently, this latter construct has led to a field of extensive research, primarily because it has been presented as a variable that explains several socio-psychological phenomena (Bardi \& Schwartz, 2003) such as polyamory (Freire, 2015) and willingness to forgive (Barbosa, 2015).

A recent study on willingness to forgive and human values using an explicit measurement has found negative correlations between willingness to forgive and personal values (achievement and experimentation); that is, the more individuals prioritize values such as pleasure, success, and power, the less willing they are to forgive. Nevertheless, when implicit measures are used, the results show a direct correlation between willingness to forgive and social values (normative and interactive; Barbosa, 2015).

Although Barbosa (2015) assesses the relationship between values and forgiveness, it should be noted that this study is based on samples drawn from the general population and academics. In light of this generalization, one may ask how these variables would function in specific samples, such as couples, specifically in predicting whether the transgressing partner is forgiven. Against this backdrop, the present article addresses marital forgiveness and its relationship with human values.

\section{Marital Forgiveness}

Forgiveness can be defined as a person's desire to forego his or her right to resentment, negative judgment, and indifferent behavior toward the offender, nurturing compassion, generosity, and love toward that person (Enright, Rique, \& Coyle, 2000). Forgiveness, then, can be understood as a process of transformation in which negative and vindictive responses are replaced by positive responses (McCullough et al., 1998).

Fincham, Paleari, and Regalia (2002) understand forgiveness as a change in motivation that occurs in interpersonal relations; that is, recovery is a process in which the desires to get revenge or to leave have subsided and the benevolent and conciliatory desires toward the offender are elevated. In this sense, forgiveness can be understood as a structure with two dimensions: (a) a negative dimension, characterized by wishing for revenge or punishment of the offender; and (b) a positive dimension, marked by increased empathy and a release from the anger, leading to a greater willingness to forgive (Fincham \& Beach, 2002; Worthington, 2003). Considering these two dimensions, Worthington (2005) suggests that when a relationship has ended, healing occurs by reducing the negative dimension. However, Fincham et al. (2006) indicate that, in ongoing relationships, a reduction in the negative dimension must be accompanied by a simultaneous increase in the positive dimension for forgiveness to be granted.

The concept of forgiveness within a marriage is not different from that in other interpersonal relationships. In principle, it requires that one of the spouses feels injured or wronged by the other (Enright \& Coyle, 1998), either by a deliberate act or through negligence (Downie, 1965). Next, the victim understands his or her right to express these negative thoughts and emotions toward the offender. If the offender wants to preserve the relationship, then he or she must demonstrate remorse and be patient, waiting for the partner's negative thoughts, feelings, and behavior to cool down (North, 1998).

The existence of instability in the marriage resulting from transgressions (such as betrayals, physical abuse, or verbal abuse) can lead to negative emotions and even result in the breakup of the marriage (Fincham, Beach, \& Davila, 2004). In this context, forgiveness can be viewed as a method of avoiding the dissolution of the marriage because it directly and positively affects conjugal satisfaction (Chung, 2014; Pelucchi, Paleari, Regalia, \& Fincham, 2013), conflict resolution (Fife, Weeks, \& StellbergFilbert, 2013), longevity (Toussaint, Owen, \& 
Cheadle, 2012) and the quality of the marriage (Fincham, Beach, \& Davila, 2007).

However, it is worth emphasizing that, despite the growing literature on marital forgiveness (Braithwaite, Selby, \& Fincham, 2011; Calo-Blanco, 2014; Hall \& Fincham, 2006; Pelucchi et al., 2013), new research is still needed to contribute to the scientific framework on the subject. The present study, for example, aims to discover the power of human values to predict the willingness of the offended partner to grant forgiveness.

\section{Functionalist Theory of Human Values}

The Functionalist Theory of Human Values proposed by Gouveia $(1998,2003,2013)$ is an integrating parsimonious model that focuses on the functions of values. According to the author (Gouveia, 1998, 2003, 2013), values have two joined functions: (a) to guide human actions (type of orientation; Rokeach, 1973; Schwartz, 1992) and (b) to express their needs (type of motivation; Inglehart, 1977; Maslow, 1954).

The two functional dimensions of values constitute the two main axes in the representation of the proposed structure: the horizontal axis corresponds to the type of orientation, and the vertical axis represents the type of motivation. Orientation values may be social, personal, or central. Individuals guided by social values are focused on society and living with others; individuals who prioritize personal values tend to be more self-centered and pursue their own interests and benefits; and individuals who share elements of these two categories are described as having central values, an innovation of the model. Thus, central values are not restricted to the dichotomy of self-centered interests (intrapersonal focus) or other-centered interests (interpersonal focus); they represent a middle position with respect to other values, serving as a type of "backbone" (Gouveia, 2013).

Motivational values can be classified as $m a$ terialistic (pragmatic), implying an orientation toward specific objectives and normative rules, typical of individuals concerned with the biological aspects of survival such as health and stability; and idealistic (humanitarian), which, unlike materialistic values, are based on more abstract principles and ideas (such as knowledge and maturity) associated with creativity and openness of spirit, suggesting lower dependence on worldly goods (Gouveia, Milfont, \& Guerra, 2014).

The intersection of these two axes results in six value subfunctions: (a) experimentation (personal-humanitarian), which encompasses the physiological need for satisfaction in a broad sense, consisting of the values of pleasure, excitement, and sexuality; (b) achievement (personal-materialistic), which encompasses the need for self-esteem, consisting of the values of success, power, and prestige; (c) existence (central-materialistic), which refers to most basic physiological and security needs, consisting of the values of health, survival, and personal stability; (d) suprapersonal (central-humanitarian), concerned with the needs of aesthetics and cognition, consisting of the values of knowledge, maturity, and beauty; (e) interactive (social-humanitarian), which represents the needs of belonging, love, and affiliation, consisting of the values of affection, social support, and coexistence; and (f) normative (social-materialistic), reflecting the importance of preserving the culture and conventional standards, consisting of the values of religion, tradition, and obedience (Gouveia, 2013).

The model proposed by Gouveia (1998) works well with various constructs such as willingness to forgive (Barbosa, 2015) and presents psychometric indicators that are appropriate at the national and international levels (e.g., Freire, 2015; Melo, 2014; Monteiro, 2014; Nascimento, 2015); however, it is not intended to replace other existing theories but rather to provide a theoretical option for conducting studies in this field.

In light of this, the use of the model described in this study appears to be justified. It is hoped that social values (Hypothesis 1) and central values (Hypothesis 2), together with their respective subfunctions, directly explain forgiveness within a marital relationship and that personal values (Hypothesis 3) and their subfunctions inversely explain the same construct. Other hypotheses warrant mention, namely, that 
there will be differences between participants with regard to the two dimensions of marital forgiveness for the following variables: (a) gender, with women being expected to score higher than men (Hypothesis 4); (b) age, with older people being expected to score higher (Hypothesis 5); (c) level of religiosity, with participants with higher levels of religiosity being expected to be more likely to forgive (Hypothesis 6); (d) length of the marriage, with spouses who have been married longer being expected to forgive more (Hypothesis 7); and (e) level of education, with people who have more schooling being expected to score higher on forgiveness (Hypothesis 8).

\section{Method}

\section{Participants}

The study is based on a non-probability convenience sample consisting of 313 individuals who are married or in a long-term relationship in the states of Paraíba $(n=219 ; 70 \%)$ and Piaui ( $n$ $=94 ; 30 \%)$. The participants ranged in age from 18 to 70 years $(M=35.00 ; S D=11.41)$; the majority were female $(n=212,67.7 \%)$, were lower middle class $(n=113 ; 36.1 \%)$, had children $(n$ $=229 ; 73.6 \%)$, had some graduate school education $(n=79 ; 25.2 \%)$, and had been in their relationship from 1 to 3 years $(n=93 ; 29.7 \%)$. They described themselves as moderately religious $(M$ $=3.67 ; S D=1.19$ ) on a scale ranging from 1 (not at all religious) to 5 (completely religious).

\section{Instruments}

The participants answered a questionnaire composed of the following instruments:

The Marital Offence-Specific Forgiveness Scale (MOFS) developed by Paleari, Regalia, and Fincham (2009) and adapted to the Brazilian context by Lopes, Fonsêca, Medeiros, Almeida, and Gouveia (2016). This scale comprises 10 items originally divided as follows: four items evaluate benevolent motivations (such as Item 2: "Although (s)he hurt me, I definitely put what happened aside so that we could resume our relationship"), and six items evaluate the motivations of resentment and revenge (such as Item 3: "Since my spouse behaved that way, I get annoyed with him/her more easily"). All of the questions are answered on a seven-point Likerttype scale, ranging from 1 (total disagreement) to 7 (total agreement). The version adapted for Brazil presents acceptable evidence of trustworthiness (Benevolence: Cronbach's alpha $=0.65$, $r_{m . i}=0.31$ and Composite Reliability $=0.66$; Avoidance-Resentment: Cronbach's alpha $=0.80, r_{m . i=0.40}$ and Composite Reliability $=$ 0.81; Lopes et al., 2016).

Basic Values Questionnaire (BVQ-18). In its updated version, this instrument comprises 18 items or specific values (Gouveia, 2013). For each item, two descriptors are presented in an attempt to represent the inherent content of the value (for example, health is described in item 9 as "being concerned with your health before you get sick" and "not being sick"). These questions are answered using a seven-point scale ranging from 1 (completely unimportant) to 7 (completely important). The instrument used by Medeiros (2011) throughout Brazil shows alphas ranging from 0.48 (interactive) to 0.63 (normative) and a homogeneity index (r.m.i) ranging from 0.24 (interactive) to 0.38 (normative) for the Brazilian context; it also shows favorable goodness of fit indices $\left[x^{2}=949.75\right.$, goodness-of-fit in$\operatorname{dex}(\mathrm{GFI})=0.92$; comparative fit index $(\mathrm{CFI})=$ 0.81 ; root mean square error of approximation $($ RMSEA $)=0.07(90 \%$ confidence interval $(\mathrm{CI})$ $=0.07-0.08)]$.

Sociodemographic Questionnaire. The participants answered a series of demographic questions, such as (a) age; (b) gender; (c) duration of the marriage or long-term-relationship, classified using an interval scale: 1-3 years, 4-7 years, 8-13 years, 14-16 years, and over 17 years; (d) number of children; (e) education: complete elementary, incomplete elementary, complete high school, incomplete high school, complete college, incomplete college, and graduate school; (f) self-perception of religiosity, expressed in a single item, on a five-point scale, ranging from 1 (not at all religious) to 5 (completely religious); (g) social class; and (h) monthly household income, expressed on a six-point scale [(1) 0 to R\$ 788; (2) R $\$ 789$ to $\mathrm{R} \$ 1,576$; (3) $\mathrm{R} \$ 1,577$ to $\mathrm{R} \$$ 2,364 ; (4) R $\$ 2,365$ to $\mathrm{R} \$ 4,728$; (5) R $\$ 4,729$ to R\$ 7,092; (6) above \$7.093]. 


\section{Data Collection Procedures}

Data were collected in two ways: by pencil and paper and online. There is evidence that data collected in person, by the traditional pencil and paper method, is adequately equivalent to data collected online (Brock, Barry, Lawrence, Dey, $\&$ Rolffs, 2012). Data were collected by the first method $(n=143)$ in public locations such as town squares, parks and shopping malls. Data were collected by the second method through a questionnaire using the Google Drive online platform. Social networks such as Facebook were used to contact potential participants ( $n$ $=170)$ in the online data collection. Data collection by both methods yielded a total of 313 participants. In both methods, care was taken to explain the general purpose of the study and to clarify that participation was voluntary, without any type of benefit or sanction, and that the participants were free to quit at any time without risking any loss. The average response time was approximately 15 minutes.

\section{Data Analysis}

Date were organized and analyzed using the SPSS statistical package, version 20, which was employed to perform descriptive statistics (e.g., mean, median, and standard deviation), multivariate analyses of variance (MANOVAs), correlations (Pearson's $r$ ) and stepwise multiple linear regression analyses.

\section{Ethical Procedures}

The project was initially developed and submitted to the Research Ethics Committee of the Center for Health Sciences of the Federal University of Paraíba (Centro de Ciências da Saúde da Universidade Federal da Paraíba [CEP/CCS]), having been approved under Protocol $0150 / 15$. Finally, it is emphasized that the study was performed following all guidelines established in National Health Council resolution $466 / 12$ on research involving human beings.

\section{Results}

\section{Correlations between Marital Forgiveness and Human Values}

Pearson's correlation coefficient (Pearson's $r$ or the product-moment correlation) was calculated in an effort to understand how the dimensions of the MOFS and the general factor (calculated as the sum of the two items of the benevolence and avoidance-resentment dimensions, with the inversion of the latter) are related to the types of orientation and their subfunctions. The results are described in Table 1.

Table 1

Correlations between Human Values and Marital Forgiveness

\begin{tabular}{lcccc}
\hline Human Values & & Benevolence & Avoidance-Resentment & $\begin{array}{c}\text { General Factor (Marital } \\
\text { Forgiveness) }\end{array}$ \\
\hline Social & $M(S D)$ & $4.46(1.40)$ & $3.34(1.39)$ & $4.55(1.18)$ \\
Interactive & $5.66(0.79)$ & $0.26^{* *}$ & 0.04 & $0.17^{*}$ \\
Normative & $5.66(0.86)$ & $0.26^{* *}$ & $-0.13^{*}$ & $0.23^{* *}$ \\
Central & $5.68(0.79)$ & $0.17^{*}$ & 0.03 & 0.09 \\
Suprapersonal & $5.42(0.85)$ & $0.16^{* *}$ & 0.001 & 0.20 \\
Existence & $5.94(0.92)$ & $0.14^{*}$ & -0.05 & $0.13^{*}$ \\
Personal & $4.66(0.92)$ & 0.10 & 0.05 & 0.05 \\
Experimentation & $4.78(1.01)$ & 0.07 & 0.06 & 0.02 \\
Achievement & $4.56(1.09)$ & 0.11 & 0.03 & 0.01 \\
\hline
\end{tabular}

Note. $M=$ mean; $S D=$ standard deviation.

$* p<.05 ; * *<.001$. 
Table 1 shows that the benevolence dimension and the general factor have significant and positive correlations with four and two value subfunctions, respectively. The benevolence dimension is correlated with the interactive subfunction $(r=0.26 ; p<.001)$; the normative subfunction $(r=0.19 ; p<.001)$; the suprapersonal subfunction $(r=0.16 ; p<.001)$; and the existence subfunction $(r=0.14 ; p=.01)$. The general factor is correlated with the interactive subfunction $(r=0.23 ; p<.001)$ and the suprapersonal subfunction $(r=0.13 ; p=.03)$. The avoidance-resentment dimension shows only an inverse correlation with the interactive subfunction $(r=-0.13 ; p=.02)$.

With regard to the types of orientation, a significant and positive correlation is observed between the benevolence dimension and two types of orientation: social orientation $(r=0.26$; $p<.001)$ and central orientation $(r=0.17 ; p=$
.01). In contrast, the avoidance-resentment dimension shows no correlation with any type of orientation. The general factor exhibits a significant and positive correlation only with the social type of orientation $(r=0.17 ; p=.01)$.

\section{Human Values as Predictors of Marital Forgiveness}

To determine the predictive power of orientation types and value subfunctions on marital forgiveness, two stepwise multiple linear regression analyses were conducted to reduce the potential for variable multicollinearity problems (Field, 2005). The value subfunctions were the predictor variables in the first analysis, and the orientation types were the predictor variables in the second analysis. The general factor, marital forgiveness, was the criterion variable in both analyses. The results of these analyses are detailed in Table 2.

Table 2

Multiple Regressions between Human Values and Marital Forgiveness

\begin{tabular}{|c|c|c|c|c|c|}
\hline Predictors & $R^{2}$ Adjusted & $F$ & $\beta$ Standardized & $t$ & $p$ \\
\hline $\begin{array}{c}\text { Types of Orientation } \\
\text { Social values }\end{array}$ & 0.03 & $F(1,303)=9.55$ & 0.17 & 6.32 & .001 \\
\hline $\begin{array}{l}\text { Subfunctions } \\
\text { Interactive }\end{array}$ & 0.05 & $F(1,303)=15.74$ & 0.22 & 3.97 & .001 \\
\hline
\end{tabular}

The first analysis shows that the interactive subfunction $[F(1,303)=15.74 ; p<.001]$ explains $5 \%$ of the total variance of marital forgiveness. It directly contributes $\left(\beta_{\text {Standardized }}=\right.$ 0.22 ) to explaining whether forgiveness between couples is granted, exhibiting significant indicators $(p<.05)$. The second regression reveals that social values $[F(1,303)=9.55 ; p<.001]$ explain $3 \%$ of marriage recovery, making this explanation significant $(t>1.96)$ and direct $\left(\beta_{\text {Standardized }}=\right.$ $0.17)$.

\section{Marital Forgiveness and Sociodemographic Variables}

To learn whether gender, education, age, duration of the relationship, and level of religi- osity make a significant difference, MANOVAs were performed based on the test of homogeneity of variance-covariance matrices (Box's M test), which yielded a non-significant associated p-value $(p=.85)$. Thus, although the samples were of different sizes, the assumption of homogeneity was guaranteed. It was determined that gender influenced the participants' scores in both dimensions [Wilks's lambda distribution $\left.=0.94, F(2,306)=9.09 ; p<.001 ; \eta^{2}=0.06\right]$. Specifically, women scored higher $(M=3.51$; $S D=1.45)$ than men $(\mathrm{M}=3.00 ; S D=1.24)$ on the avoidance-resentment dimension $[F(1$, $307)=9.14 ; p=.003]$; an inverse relationship was observed for the benevolence dimension, on which men scored higher $(M=4.91 ; S D=1.30)$ 
than women $(M=4.24 ; S D=1.40)[F(1,307)=$ $15.90 ; p<.001]$.

It is observed that level of education [Wilks's lambda $=0.91 ; F(12,602)=2.29 ; p=$ $\left..007 ; \eta^{2}=0.04\right]$ makes a difference only to the avoidance-resentment dimension $[F(6,302)=$ $3.12 ; p=.006]$. Specifically, a comparison of the groups using the Bonferroni post hoc test shows that individuals with an incomplete elementary education $(M=4.38 ; S D=1.54)$ score higher than those with a college degree $(M=3.16 ; S D$ $=1.28)$ or graduate study $(M=3.04 ; S D=1.38)$. The likelihood of marital forgiveness does not appear to be significantly influenced by the $d u$ ration of the relationship [Wilks's Lambda $=$ $\left.0.97 ; F(10,544)=0.75 ; p=.67 ; \eta^{2}=0.01\right]$, age [Wilks's Lambda $=0.99 ; F(4,610)=0.71 ; p=$ $\left..59 ; \eta^{2}=0.005\right]$, or self-perception of religiosity $[$ Wilks's Lambda $=0.99 ; F(2,229)=0.45 ; p=$ $\left..64 ; \eta^{2}=0.004\right]$.

\section{Discussion}

As noted above in the discussion of the correlations, the results demonstrate that social values are good predictors of marriage recovery, corroborating hypothesis 1 . This finding matches studies on pro-social behaviors (Dalbert, 2002; Strelan, 2007) because the interactive subfunction represents individuals who express concern for others, expressing feelings of care and affection; and the normative subfunction is characteristic of religious people who fulfill their obligations, promote social harmony (Gouveia, 2003, 2013), and foster closer, more well-adjusted relationships, avoiding feelings of avoidance and resentment (Gordon \& Baucom, 1998). In this sense, people guided by social values are more predisposed to grant forgiveness, corroborating the findings of Strelan and McKee (2014).

Moreover, it is found that the subfunction that best explains recovery of the marital relationship is the interactive subfunction, supporting the hypothesis discussed above. This finding can be explained by the nature of this subfunction, which is essential to the establishment, regulation, and maintenance of interpersonal re- lationships (Gouveia, 2013), such as a marriage (Hook, Worthington, Utsey, Davis, \& Bumette, 2012).

Central values and their subfunctions do not prove to be good predictors of marital forgiveness, disproving hypothesis 2. However, it is possible to verify that the existence subfunction shows a significant positive correlation with the benevolence dimension and the general factor (marital forgiveness). According to some authors (Lawler-Row, Scott, Rains, Edlis-Matityahou, \& Moore, 2007; Younger, Piferi, Jobe, \& Lawler, 2004), victims of offenses may view forgiveness as a factor that will benefit them more than situations of intense negative feelings toward the aggressor, coming to understand recovery as selfhealing.

In turn, the suprapersonal subfunction shows a positive correlation with the benevolence dimension. This relationship can be explained by the theoretical nature of the subfunction, which expresses the importance of abstract ideas (Inglehart, 1991), emphasizing thought in a broader sense (Schwartz, 1992). Thus, forgiveness can be viewed as an intrapersonal process leading the subject to self-actualization (Braithwaite \& Law, 1985).

The findings show that personal values, including their subfunctions (experimentation and fulfillment), are not good predictors of marriage recovery, disproving hypothesis 3 , and they bear no significant relation to marital forgiveness and its dimensions. Nevertheless, it was expected that people guided by personal values would demonstrate a low ability to grant their partners forgiveness due to the egocentric nature of individuals guided by these values (Gouveia, 2013; Gouveia, Fonsêca, Milfont, \& Fischer, 2011), surmising that little concern for others would translate into little disposition to forgive (Strelan $\&$ McKee, 2014).

It is believed that the findings of this study do not match those of other studies in the literature due to the characteristics of this study's sample: the majority of the participants in this study report being in their current marriage or relationship between one and three years. Accord- 
ing to Wagner, Ribeiro, Arteche, and Bornholdt (1999), the early stage of marriage is marked by efforts by both partners to strengthen unity and love, often foregoing personal desires for the good of the couple, reflecting an increase in tolerance, understanding, and forgiveness.

Finally, it should be noted that the values noted and discussed above regarding relationships are considered significantly weak (less than 0.30) based on the magnitudes considered (Cohen, 1998). Nevertheless, the malleability of the constructs used should be considered because, according to Hemphill (2003), finding correlations above 0.30 in psychology seem to be an exception rather than the rule. The results, then, should be viewed as exploratory and subject to replication.

Among the sociodemographic variables (gender, education, age, duration of marriage, level of religiosity), it is shown that only gender and education significantly influence the subjects with regard to marital forgiveness, supporting only hypotheses 4 and 8 . In relation to gender, it is found that men are more benevolent and that women are more likely to display behaviors of avoidance and resentment.

This pattern is also found in the study by Sales (2014) but is not corroborated by most findings in the literature (McCullough, Bellah, Kilpatrick, \& Johnson, 2001; Mullet, Houdbine, Laumonier, \& Girard, 1998), which indicate that women are more predisposed to recover the marriage in view of their desire to establish and maintain harmonious relations in their interactions. Men present a more vindictive profile, being able to express aggressive behavior and take justice into their own hands. However, it is necessary to consider the cultural context of northeastern Brazil, where this study was performed, because the behavioral differences regarding forgiveness most likely vary from culture to culture (Sandage \& Williamson, 2005).

The factor of education displays only a negative correlation because subjects with incomplete elementary school score higher than those with a college degree or graduate study. This finding expresses the influence of maturity acquired during the course of education (Souza \& Wechsler, 2013), which is an important factor in the decision of whether to forgive (Allemand $\&$ Steiner, 2012).

With regard to age, this study corroborates the findings by Sandage, Worthington, Hight, and Berry (2000) that there is no relationship between age and forgiveness. Nevertheless, some authors (Allemand, 2008; Ghaemmaghami, Allemand, \& Martin, 2011; Steiner, Allemand, \& McCullough, 2012) indicate that older people tend to have a greater ability to forgive than do younger people, contradicting hypothesis 5 . This can be a result of older individuals' greater experience with interpersonal problems and transgressions over the course of their lives (Allemand \& Steiner, 2012), leading people with more experience to concentrate on more significant emotional aspects, such as the maintenance of relationships, allowing them to grant their offender forgiveness more easily (Lang \& Carstensen, 2002).

Religiosity also has no influence on the participants' scores with regard to marital forgiveness, disproving hypothesis 6 . This result corresponds to the findings of Rique and Camino (2010), who note a lack of correlation between different levels of religiosity and forgiveness in a Brazilian sample. This may be a result of using only a single item (Gouveia et al., 2009), similar to that employed in the present study. However, it was expected that people with higher levels of religiosity would be more likely to grant forgiveness, considering they believe that marriage is sacred and its dissolution is an act of disrespect toward divine order (Krumrei, Mahoney, \& Pargament, 2011).

Moreover, the duration of the relationship also shows no significant difference between the averages for the benevolence and avoidanceresentment dimensions, differing in this respect from some studies (Guilford \& Bengton, 1979; Rollins \& Feldman, 1970), which indicate that those in comparatively recent relationships (1-3 years) and long-term relationships (over 17 years) are more likely to forgive the partner over time and in different situations to preserve har- 
mony and maintain the relationship (Guilford \& Bengton, 1979; Rollins \& Feldman, 1970). Thus, the findings do not corroborate hypothesis 7.

In light of these results, it is believed that social values are important predictors for marital forgiveness, providing an empirical framework to develop clinical techniques and interventions that aim to solve problems and/or conflicts stemming from marital interactions. Although the proposed objectives have been achieved, possible limitations must also be acknowledged. For example, the use of a non-probability convenience sample (Cozby, 2003) restricts the ability to generalize the findings. However, this issue does not invalidate or undermine the results, given that the study was not designed for that purpose.

Another important point to consider is the possibility that the participants' answers may have been influenced by social desirability; that is, the respondents may have claimed to be more willing to forgive than they actually are, having given what they consider to be more socially acceptable responses. This pattern is common with measures that rely on self-reporting (Anastasi \& Urbina, 2000) such as those used in the present study (the Marital Offense-Specific Forgiveness Scale and the Basic Values Questionnaire).

In light of these results, it is hoped that this article contributes to the literature on the constructs addressed here; however, given the limitations of this study, it is suggested that further research on this theme be undertaken. It is recommended that future studies use a larger and more diverse sample that has been chosen randomly, including individuals from a variety of Brazilian states, because it is understood that cultural orientation can vary from one region in Brazil to another (Gouveia, Albuquerque, Clemente, \& Espinosa, 2002; Hofstede, Hofstede, \& Minkov, 2010), which may have an impact on marital forgiveness and human values.

\section{Reference}

Abreu, E. L. (2013). A relação entre o pensamento moral da justiça e o pensamento moral do perdão (Master's thesis, Department of Psychol- ogy, Federal University of Paraíba, João Pessoa, PB, Brazil). Retrieved from http://tede.biblioteca.ufpb.br/bitstream/tede/6917/1/arquivototal. pdf

Allemand, M. (2008). Age differences in forgivingness: The role of future time perspective. Journal of Research in Personality, 42(5), 11371147. doi:10.1016/j.jrp.2008.02.009

Allemand, M., \& Steiner, M. (2012). Situation-specific forgiveness and dispositional forgiveness: A lifespan development perspective. In E. Kahls \& J. Maes (Eds.), Justice psychology and conflicts: Theoretical and empirical contributions (pp. 361-375). New York: Springer.

Allemand, M., Steiner, M., \& Hill, P. L. (2013). Effects of a forgiveness intervention for older adults. Journal of Counseling Psychology, 60(2), 279-286. doi:10.1037/a0031839

Anastasi, A., \& Urbina, S. (2000). Testagem psicológica. Porto Alegre, RS: Artes Médicas.

Barbosa, L. H. G. M. (2015). Explicando a disposição para perdoar: O papel dos valores humanos $e$ das crenças ao mundo justo/injusto (Master's thesis, Department of Psychology, Federal University of Paraíba, João Pessoa, PB, Brazil). Retrieved from http://bdtd.biblioteca.ufpb.br/ bitstream/tede/7565/2/arquivototal.pdf

Bardi, A., \& Schwartz, S. H. (2003). Values and behavior: Strength and structure of relations. Personality and Social Psychology Bulletin, 29(10), 1207-1220. doi:10.1177/0146167203254602

Braithwaite, V. A., \& Law, H. G. (1985). Structure of human values: Testing the adequacy of the Rokeach Value Survey. Journal of personality and social psychology, 49(1), 250-263. doi:10.1037/0022-3514.49.1.250

Braithwaite, S. R., Selby, E. A., \& Fincham, F. D. (2011). Forgiveness and relationship satisfaction: Mediating mechanisms. Journal of Family Psychology, 25(4), 551-559. doi:10.1037/ a0024526

Brock, R. L., Barry, R. A., Lawrence, E., Dey, J., \& Rolffs, J. (2012). Internet administration of paper-and-pencil questionnaires used in couple research: Assessing psychometric equivalence. Assessment, 19(2), 226-242. doi:10.1177/1073191110382850

Bueno, R. K., Souza, S. A., Monteiro, M. A., \& Teixeira, R. H. M. (2013). Processo de diferen- 
ciação dos casais de suas famílias de origem. Psico, 44(1), 16-25. Retrieved from http://revistaseletronicas.pucrs.br/ojs/index.php/revistapsico/article/viewArticle/9420

Calo-Blanco, A. (2014). Fairness, freedom, and forgiveness in health care. Social Choice and Welfare, 43(1), 141-151. doi:10.1007/s00355-0130774-7

Chung, M. S. (2014). Pathways between attachment and marital satisfaction: The mediating roles of rumination, empathy, and forgiveness. Personality and Individual Differences, 70(6), 246-251. doi:10.1016/j.paid.2014.06.032

Cohen, J. (1988). Statistical power analysis for the behavioral sciences $\left(2^{\text {nd }}\right.$ ed.). Hillsdale, NJ: Erlbaum.

Cozby, P. C. (2003). Métodos de pesquisa em ciências do comportamento. São Paulo, SP: Atlas.

Dalbert, C. (2002). Beliefs in a just world as a buffer against anger. Social Justice Research, 15(2), 123-145. doi:10.1023/A:1019919822628.

Downie, R. S. (1965). Forgiveness. Philosophical Quarterly, 15(59), 128-134. doi:10.2307/2218212

Enright, R. D., \& Coyle, C. T. (1998). Researching the process model of forgiveness within psychological interventions. In E. L. Worthington (Ed.), Dimensions of forgiveness: Psychological research and theological perspectives (pp. 139161). Philadelphia, PA: Templeton Press.

Enright, R. D., Rique, J., \& Coyle, C. T. (2000). Enright forgiveness inventory user's manual, Redwood City, CA: Mind Garden.

Field, A. (2005). Discovering Statistics Using SPSS ( $2^{\text {nd }}$ ed.). London: Sage.

Fife, S. T., Weeks, G. R., \& Stellberg-Filbert, J. (2013). Facilitating forgiveness in the treatment of infidelity: An interpersonal model. Journal of Family Therapy, 35(4), 343-367. doi:10.1111/ j.1467-6427.2011.00561.x

Fincham, F. D., \& Beach, S. R. H. (2002). Forgiveness in marriage: Implications for psychological aggression and constructive communication. Personal Relationships, 9(3), 239-251. doi:10.1111/1475-6811.00016

Fincham, F. D., Beach, S. R., \& Davila, J. (2004). Forgiveness and conflict resolution in marriage. Journal of Family Psychology, 18(1), 72-81. doi:10.1037/0893-3200.18.1.72
Fincham, F. D., Beach, S. R., \& Davila, J. (2007). Longitudinal relations between forgiveness and conflict resolution in marriage. Journal of Family Psychology, 21(3), 542-545. doi:10.1037/08933200.21 .3 .542

Fincham, F. D., Hall, J., \& Beach, S. R. (2006). Forgiveness in marriage: Current status and future directions. Family Relations, 55(4), 415-427. doi:10.1111/j.1741-3729.2005.callf.x-i1

Fincham, F. D., Paleari, F. G., \& Regalia, C. (2002). Forgiveness in marriage: The roles of relationship quality, attributions and emotions. Personal Relationships, 9(1), 27-37.

Freire, L. A. (2015). Atitudes frente á homoparentalidade: Uma explicação a partir de variáveis explícitas e implicitas (Doctoral dissertation, Department of Psychology, Federal University of Paraíba, João Pessoa, PB, Brazil). Retrieved from http://tede.biblioteca.ufpb.br/bitstream/ tede/7521/2/arquivototal.pdf

Ghaemmaghami, P., Allemand, M., \& Martin, M. (2011). Forgiveness in younger, middle-aged and older adults: Age and gender matters. Journal of Adult Development, 18(4), 192-203. doi:10.1007/s10804-011-9127-x

Gordon, K. C., \& Baucom, D. H. (1998). Understanding betrayals in marriage: A synthesized model of forgiveness. Family Process, 37(4), 425-449. doi:10.1111/j.1545-5300.1998.00425.x

Gouveia, V. V. (1998). La naturaleza de los valores descriptores del individualismo e del colectivismo: una comparación intra e intercultural (Doctoral dissertation, Department of Psychology, Complutense University of Madri, Spain).

Gouveia, V. V. (2003). A natureza motivacional dos valores humanos: Evidências acerca de uma nova tipologia. Estudos de Psicologia (Natal), 8(3), 431-443. doi:10.1590/S1413294X2003000300010

Gouveia, V. V. (2013). Teoria Funcionalista dos Valores Humanos: Fundamentos, aplicações e perspectivas. São Paulo, SP: Casa do Psicólogo.

Gouveia, V. V., Albuquerque, F. J. B., Clemente, M., \& Espinosa, P. (2002). Human values and social identities: A study in two collectivist cultures. International Journal of Psychology, 37(6), 333342. doi: $10.1080 / 00207590244000179$

Gouveia, V. V., Fonseca, P. N., Milfont, T. L., \& Fischer, R. (2011). Valores humanos: Contribuições e perspectivas teóricas. In C. V. Torres 
\& E. R. Neiva (Eds.), A psicologia social: Principais temas e vertentes (pp. 296-313). Porto Alegre, RS: ArtMed.

Gouveia, V. V., Gonçalves, M. P., Costa, J. D. M., Araújo, L. B. U. D., Gouveia, R. S., \& Medeiros, E. D. D. (2009). Disposição para perdoar, desejabilidade social e religião: Um estudo correlacional. Revista Bioética, 17(2)-297-308.

Gouveia, V.V., Milfont, T. L., \& Guerra, V. M. (2014). Functional theory of human values: Testing its content and structure hypotheses. Personality and Individual Differences, 60, 4147. doi:10.1016/j.paid.2013.12.012

Guilford, R., \& Bengtson, V. (1979). Measuring marital satisfaction in three generations: Positive and negative dimensions. Journal of Marriage and the Family, 41(2), 387-398. doi:10.2307/351705

Hall, J. H., \& Fincham, F. D. (2006). Relationship dissolution following infidelity: The roles of attributions and forgiveness. Journal of Social and Clinical Psychology, 25(5), 508-522. doi:10.1521/jscp.2006.25.5.508

Hemphill, J. F. (2003). Interpreting the magnitudes of correlation coefficients. American Psychologists, 58(1), 78-80. Retrieved from https://www. ncbi.nlm.nih.gov/pubmed/12674822

Hofstede, G., Hofstede, G. J., \& Minkov, M. (2010). Cultures and organizations: Software of the mind. London: McGraw-Hill.

Hook, J. N., Worthington, E. L., Utsey, S. O., Davis, D. E., \& Burnette, J. L. (2012). Collectivistic self-construal and forgiveness. Counseling and Values, 57(1), 109-124. doi:10.1002/j.2161007X.2012.00012.x

Inglehart, R. (1977). The silent revolution: Changing values and political styles among Western publics. Princeton, NJ: Princeton University Press.

Inglehart, R. (1991). El cambio cultural en las sociedades industriales avanzadas. Madri: Siglo XXI.

Krumrei, E. J., Mahoney, A., \& Pargament, K. I. (2011). Spiritual stress and coping model of divorce: A longitudinal study. Journal of Family Psychology, 25(6), 973-985. doi:10.1037/ a0025879

Lander, I. (2012). Towards the incorporation of forgiveness therapy in healing the complex trauma of parental incarceration. Child and Adolescent Social Work Journal, 29(1), 1-19. doi:10.1007/ s10560-011-0248-7
Lang, F. R., \& Carstensen, L. L. (2002). Time counts: Future time perspective, goals, and social relationships. Psychology and aging, 17(1), 125139. doi:10.1037/0882-7974.17.1.125

Lawler-Row, K. A., Scott, C. A., Raines, R. L., EdlisMatityahou, M., \& Moore, E. W. (2007). The varieties of forgiveness experience: Working toward a comprehensive definition of forgiveness. Journal of Religion and Health, 46(2), 233-248. doi:10.1007/s10943-006-9077-y

Lin, Y., Worthington, E. L., Griffin, B. J., Greer, C. L., Opare-Henaku, A., Lavelock, C. R., ... Muller, H. (2014). Efficacy of reach forgiveness across cultures. Journal of Clinical Psychology, 70(9), 781-793. doi:10.1002/jclp.22073

Lopes, B. J., Fonsêca, P. N., Medeiros, E. D., Almeida, A. C., \& Gouveia, V. V. (2016). Escala de perdão conjugal (MOFS): Evidências de validade de construto no contexto brasileiro. Psico, 47(2), 121-131. doi:10.15448/19808623.2016.2.22439

Maslow, A. H. (1954). Motivation and personality. New York: Harper and Row.

McCullough, M. E., Bellah, G. C., Kilpatrick, S. D., \& Johnson, J. L. (2001). Vengefulness: Relationships with forgiveness, rumination, well-being, and the Big Five. Personality and Social Psychology Bulletin, 27(5), 601-610. doi:10.1177/0146167201275008

McCullough, M. E., Rachal, K., Sandage, S., Worthington, E. L., Brown, S., \& Hight, T. (1998). Interpersonal forgiving in close relationships: II. Theoretical elaboration and measurement. Journal of Personality and Social Psychology, 75(6), 1586-1603. doi:10.1037/0022-3514.75.6.1586

Medeiros, E. D. (2011). Teoria Funcionalista dos Valores Humanos: Testando sua adequação intra e interculturalmente (Doctoral dissertation, Departamento de Psicologia, Universidade Federal da Paraíba, João Pessoa, PB, Brazil).

Melo, R. L. P. (2014). Correlatos valorativos das atitudes frente à aposentadoria (Masters thesis, Department of Psychology, Federal University of Paraíba, João Pessoa, PB, Brazil). Retrieved from http://www.vvgouveia.net/index.php? option $=$ com_phocadownload\&view $=$ category $\&$ $\mathrm{id}=18 \&$ Itemid=175\&lang=pt-br

Monteiro, R. P. (2014). Entendendo a Psicopatia: Contribuição dos traços de personalidade e valores humanos (Masters thesis, Department of 
Psychology, Federal University of Paraíba, João Pessoa, PB, Brazil). Retrieved from http://tede. biblioteca.ufpb.br/bitstream/tede/7564/2/arquivototal.pdf

Mullet, E., Houdbine, A., Laumonier, S., \& Girard, M. (1998). "Forgiveness:" Factor structure in a sample of young, middle-aged, and elderly adults. European Psychologist, 3(4), 289-297. doi:10.1002/9781118339893.wbeccp228

Nascimento, B. S. (2015). Atitudes frente à violência contra a mulher: O papel dos valores e da desumanização da mulher (Masters thesis, Department of Psychology, Federal University of Paraíba, João Pessoa, PB, Brazil). Retrieved from http://tede.biblioteca.ufpb.br/bitstream/ tede/7643/2/arquivototal.pdf

North, J. (1998). The "ideal" of forgiveness: A philosopher's exploration. In R. D. Enright \& J. North (Eds.), Exploring forgiveness (pp. 15-45). Madison, WI: University of Wisconsin Press.

Paleari, F. G., Regalia, C., \& Fincham, F. D. (2009). Measuring offence-specific forgiveness in marriage: The Marital Offence-Specific Forgiveness Scale (MOFS). Psychological Assessment, 21(2), 194-209. doi:10.1037/a0016068

Peets, K., Hodges, E. V., \& Salmivalli, C. (2013). Forgiveness and its determinants depending on the interpersonal context of hurt. Journal of Experimental Child Psychology, 114(1), 131-145. doi:10.1016/j.jecp.2012.05.009

Pelucchi, S., Paleari, F. G., Regalia, C., \& Fincham, F. D. (2013). Self-forgiveness in romantic relationships: It matters to both of us. Journal of Family Psychology, 27(4), 541-549. doi:10.1037/ a0032897

Rique, J., \& Camino, C. P. S. (2010). O perdão interpessoal em relação a variáveis psicossociais e demográficas. Psicologia Reflexão e Crítica, 23(3), 525-532.

Rokeach, M. (1973). The nature of human values. New York: Free Press.

Rollins, B. C., \& Feldman, H. (1970). Marital satisfaction over the family life cycle. Journal of Marriage and the Family, 32(1), 20-28. doi:10.2307/349967

Sales, H. F. S. (2014). Disposição para perdoar $e$ sua associação com saúde geral e variáveis sociodemográficas (Completion of course work, Department of Psychology, Federal University of Píaui, Parnaiba, PI, Brazil).
Sandage, S. J., \& Williamson, I. (2005). Forgiveness in cultural context. In E. L. Worthington (Ed.), Handbook of forgiveness (pp. 41-55). New York: Brunner-Routledge.

Sandage, S. J., Worthingon, E. L., Jr., Hight, T. L., \& Berry, J. W. (2000). Seeking forgiveness: Theoretical context and an initial empirical study. Journal of Psychology and Theology, 28(1), 2135. doi:10.091-6471/410-730

Schwartz, S. H. (1992). Universal in the content and structure of values: Theoretical advances and empirical tests in 20 countries. In M. P. Zanna (Ed.), Advanced in experimental social psychology (pp. 1-65). New York: Academic Press.

Souza, A. A. F., \& Wechsler, S. M. (2013). Inteligência e criatividade na maturidade e velhice. Psicologia: Reflexão e Crítica, 26(4), 643-653. Retrieved from http://www.scielo.br/pdf/prc/ v26n4/04.pdf

Steiner, M., Allemand, M., \& McCullough, M. E. (2012). Do agreeableness and neuroticism explain age differences in the tendency to forgive others? Personality and Social Psychology Bulletin, 38(4), 441-453. doi:10.1177/0146167211427923

Strelan, P. (2007). The prosocial, adaptive qualities of just world beliefs: Implications for the relationship between justice and forgiveness. Personality and Individual Differences, 43(4), 881-890. doi:10.1016/j.paid.2007.02.015

Strelan, P., \& McKee, I. (2014). Inclusive justice beliefs and forgiveness: Commonality through self-transcending values. Personality and Individual Differences, 68, 87-92. doi:10.1016/j. paid.2014.04.001

Strelan, P., McKee, I., Calic, D., Cook, L., \& Shaw, L. (2013). For whom do we forgive? A functional analysis of forgiveness. Personal Relationships, 20(1), 124-139. doi:10.1111/j.14756811.2012.01400.x

Toussaint, L. L., Owen, A. D., \& Cheadle, A. (2012). Forgive to live: Forgiveness, health, and longevity. Journal of Behavioral Medicine, 35(4), 375386. doi:10.1007/s10865-011-9362-4

Wagner, A., \& Mosmann, C. (2012). Intervenção na conjugalidade: Estratégias de resolução de conflitos conjugais. In. M. N. Baptista \& M. L. M. Teodoro (Eds.), Psicologia de família: Teoria, avaliação e intervenções (pp. 240-248). Porto Alegre, RS: Artmed. 
Wagner, A., Ribeiro, L. D. S., Arteche, A. X., \& Bornholdt, E. A. (1999). Configuração familiar e o bem-estar psicológico dos adolescentes. Psicologia: Reflexão e Crítica, 12(1), 147-156. doi:10.1590/S0102-79721999000100010

Witvliet, V. O. C. (2001). Forgiveness and health: Review and reflections on a matter of faith, feelings, and physiology. Journal of Psychology and Theology, 29(3), 212. Retrieved from http:// go.galegroup.com/ps/i.do? id $=$ GALE $\% 7 C A 797$ $57933 \& \mathrm{v}=2.1 \& \mathrm{u}=$ capes $\& \mathrm{it}=\mathrm{r} \& \mathrm{p}=\mathrm{AONE} \& \mathrm{sw}=$ w\&asid $=3$ ba970013b90e1dea857b9505a375a2f

Worthington, E. L. (2003). Forgiving and reconciling: Bridges to wholeness and hope. Downers Grove, IL: Inter Varsity Press.
Worthington, E. L. (2005). Handbook of forgiveness. New York: Routledge.

Younger, J. W., Piferi, R. L., Jobe, R. L., \& Lawler, K. A. (2004). Dimensions of forgiveness: The views of laypersons. Journal of Social and Personal Relationships, 21(6), 837-855. doi: $10.1177 / 0265407504047843$

Received: 03/07/2016

$1^{\text {st }}$ revision: $28 / 10 / 2016$

Accepted: 28/11/2016 